\title{
PENGEMBANGAN DAN DINAMIKA MODA PRODUKSI USAHA PETERNAKAN SAPI PERAH DI PANGALENGAN JAWA BARAT
}

\author{
M. Ali Mauludin ${ }^{1}$, Syahirul Alim¹., dan Viani P. Sari ${ }^{2}$ \\ ${ }^{1}$ Fakultas Peternakan Universitas Padjadjaran. \\ ${ }^{2}$ Fakultas Ilmu Sosial dan Ilmu Politik Universitas Padjadjaran \\ E-mail:mali.mauludin@unpad.ac.id
}

\begin{abstract}
ABSTRAK : Pangalengan telah menjadi salah satu sentra peternakan sapi perah terkemuka di Jawa Barat selain Lembang Kabupaten Bandung Barat. Hingga saat ini, hal tersebut masih terus berlangsung bahkan Pangalengan ditetapkan sebaga ikon peternakan sapi perah Jawa Barat. Penelitian ini bertujuan untuk menganalisis pengembangan peternakan sapi perah dan dinamika moda produksi usaha peternakan sapi perah di Pangalengan dari masa ke masa mulai dari awal keberadaannya hingga saat ini. Metode penelitian yang digunakan adalah metode kualitatif dengan pendekatan studi kasus. Hasil penelitian menunjukkan bahwa pengembangan peternakan sapi perah di Pangalengan terklasifikasi menjadi tiga periode yaitu periode penjajahan (sebelum 1945), periode Perintis (tahun 1945 sampai 1975), dan periode Kontemporer (1975 s/d sekarang) sedangkan dinamika moda produksi usaha peternakan sapi perah terbentuk pada periodisasi tersebut antara lain capitalist, semi-petty commodity, petty commodity. Kekuatan produksi di tiap periode adalah ternak sapi perah, lahan dan keterampilan peternak. Sedangkan yang membedakan dari keseluruhan periode tersebut adalah jumlah penguasaan ternak, ketersediaan lahan yang berkurang serta meningkatnya keterampilan peternak yang didukung oleh kemajuan teknologi dan pengetahuan. Dalam hubungan produksi, terjadi transformasi hubungan kerja dan munculnya jenis pekerjaan baru.
\end{abstract}

Kata kunci: pengembangan, moda produksi, sapi perah, pangalengan

\section{DEVELOPMENT AND MODE OF PRODUCTION DYNAMIC OF DAIRY FARMING BUSINESS IN PANGALENGAN WEST JAVA}

\begin{abstract}
Pangalengan has been one of the leading dairy farming centre in West Java besids Lembang, West Bandung Regency since 1990s. Until recently it has become more famous and has been appointed as dairy farming icon of West Java. This research was aimed to analyze development of dairy farming and mode of production dynamic of dairy farming which consist of production forces and production relations dimensions on dairy farmer community in Pangalengan from time to time from the its early existence until today. Research method used in this research was qualitative method with case study approach. The result showed that development of dairy farming in Pangalengan could be classified into three periods: Period of Occupation (before 1945), period of pioneering (1945-1975) and period of Contemporary $(1975$ - now). While mode of production dynamics formed in those periodisation were capitalist, semipetty commodity and petty commodity. Production forces in each period were dairy cow, land and dairy farmers'skills. Meanwhile, the differentiation from all periods were the number of dairy ownership, availability of decreasing land, and increasing skills of dairy farmer which supported by technological and scientific advancement. In production relations, there have been transformation of working relations and the new emerging work types.
\end{abstract}

Key words: Development, Mode of Production, Dairy Cow, Pangalengan

\section{PENDAHULUAN}

Pangalengan sudah sejak lama dikenal sebagai sentra penghasil sapi perah di Propinsi Jawa Barat. Wilayah yang merupakan salah satu Kecamatan di Kabupaten Bandung ini dapat dikatakan menjadi ikon bagi peternakan sapi perah Jawa Barat. Menurut Homzah (1986) ternak sapi perah masuk ke Pangalengan sebelum tahun 1860, saat beberapa keluarga Belanda mulai memelihara sapi untuk tujuan memenuhi kebutuhan sehari-hari rumah tangga mereka. Baru pada tahun 1860 sapi perah mulai dipelihara secara komersial. Hal ini ditandai dengan didirikannya beberapa perusahaan peternakan sapi perah oleh bangsa Belanda di antaranya de Friesche Trep, Almanak, Van der Est dan Bigman dengan target pemasarannya sebagian besar adalah orang-orang Belanda yang berdomisili di Pangalengan, kawasan Bandung dan sekitarnya.

Dinamika yang cukup mempengaruhi kehidupan masyarakat terutama setelah peralihan penjajahan dari Belanda kepada Jepang pada sekitar 1942. Menurut Umboh dalam Subandriyo dan Adiarto (2009) pada periode pendudukan Jepang, perusahaan sapi perah Belanda diambil alih oleh Pemerintah Pendudukan Jepang. Pada masa itu, pengelolaannya berlangsung secara darurat, di mana ketersediaan bahan baku konsentrat mengalami keterbatasan. Sebagai akibatnya, produksi susu sapi mengalami penurunan yang tajam, akan tetapi di sisi lain harga pakan konsentrat mengalami peningkatan. 
Modernisasi di bidang pertanian menjadikan perubahan yang sangat mendasar pada kehidupan masyarakat Indonesia, hal serupa terjadi pula pada sub sektor peternakan. Peternakan sapi perah sejak dahulu sudah ada daerah Jawa, terutama Jawa Barat dengan jenis atau bangsa sapi perah yang berkembang adalah bangsa Fries Holland (FH) yang benar murni dan mutu terbaik. Peternak sebagai subyek dalam pembangunan peternakan memberikan perubahan dalam tatanan komunitas peternak sapi perah, bahwa modernisasi dalam konteks pembangunan dapat membentuk struktur sosial yang baru. Peternakan yang berlaku di Indonesia diselenggarakan oleh peternak subsisten tradisional yang mengusahakan produksi dengan seadanya tapi dengan berkembangnya jaman dan dengan gencarnya pembangunan di berbagai sektor maka peralihan kondisi produksi peternakan sapi perah pun terjadi.

Dinamika perkembangan usaha peternakan sapi perah tidak terlepas dari adanya institusi atau kelembagaan formal yakni Koperasi. Keberadaan koperasi peternakan memberikan warna perubahan dalam kehidupan masyarakat di daerah Pangalengan Jawa Barat.Berbagai studi mengenai modernisasi dan pembangunan yang berimplikasi terhadap perubahan struktur masyarakat pedesaan,kebanyakan masih berpusat pada kasus masyarakat agraris yang dalam konteks ekologi padi sawah dan perkebunan serta pada sektor perikanan. Dengan demikian,sub sektor peternakan menjadi sangat menarik untuk diteliti dan dikaji serta ditelaah lebih dalam mengenai pengembangan peternakan sapi perah dari masa ke masa serta dinamika moda produksi usaha peternakan sapi perah, terlebih daerah tersebut memiliiki catatan sejarah dari masa penjajahan hingga sekarang.

Berdasarkan latar belakang, maka tujuan dari penelitian ini adalah menganalisis pengembangan peternakan sapi perah dan dinamika moda produksi usaha peternakan sapi perah dalam konteks formasi sosial yang terjadi di Pangalengan Kabupaten Bandung Propinsi Jawa Barat dari masa ke masa.

\section{METODE}

Penelitian dilaksanakan diKecamatanPangalengan Kabupaten Bandung dan merupakan wilayah kerja Koperasi Peternakan Bandung Selatan (KPBS). KPBS memiliki wilayah kerja di tiga kecamatan yaitu kecamatan Pangalengan, kecamatan Kertasari dan kecamatan Pacet. Dari ketiga kecamatan tersebut, Kecamatan Pangalengan memiliki jumlah populasi ternak sapi perah terbesar dan lokasi kantor KPBS berada di kecamatan Pangalengan. Pemilihan tempat atau lokasi tersebut didasarkan atas sentra peternakan sapi perah di Kabupaten Bandung Propinsi Jawa Barat. Melalui metode kualitatif, realitas sosial yang dijadikan lapangan studi dipahami sebagai realitas historis. Data dan informasi multi-metode yaitu dengan melakukan pengamatan langsung di lapangan, melakukan wawancara mendalam dengan informan dan melakukan studi dokumentasi/ arsip.

Data yang dikumpulkan berupa data primer maupun data sekunder. Data primer mencakup datadata yang relevan untuk menjawab berbagai pertanyaan penelitian. Wawancara mendalam dilakukan dengan beberapa tokoh masyarakat, perangkat desa dan kecamatan, pengurus koperasi dan rumah tangga pada komunitas peternak sapi perah. Sedangkan, data sekunder yang mencakup tentang keadaan geografi, demografi, pemerintahan desa, kegiatan perekonomian desa, penyebaran ternak sapi perah, dan data produksi susu sapi. Data ini diperoleh dari dokumen, arsip tertulis atau laporan hasil penelitian, dan publikasi lainnya yang bersumber dari KPBS, Dinas Peternakan Kabupaten Bandung, kantor kecamatan Pangalengan, kantor desa Pangalengan serta data BPS Kabupaten Bandung.

Pengujian keabsahan data dilakukan dengan menggunakan teknik triangulasi yaitu check, recheck, dan cross check terhadap data yang diperoleh (Creswell, 1994). Selanjutnya, Menurut Yin (2002) model analisis data dibagi dalam tiga komponen pokok, yaitu: (1) reduksi data, yaitu memilih, dan menyederhanakan data kasar yang diperoleh di lapangan; (2) penyajian data, yaitu penyajian data dilakukan dengan menggunakan tabel atau matriks supaya memudahkan dalam melihat apa yang sedang terjadi dan terkait dengan tema penelitian; dan (3) penarikan kesimpulan dengan cara melakukan verifikasi selama penelitian berlangsung secara berulang-ulang guna memperoleh kebenaran data atau informasi yang valid. Selanjutnya data tersebut diinterpretasikan secara deskriptif, kemudian ditarik suatu kesimpulan.

\section{HASIL DAN PEMBAHASAN}

\section{Gambaran Umum Kecamatan Pangalengan}

Berdasarkan letak geografis dan demografis maka kecamatan Pangalengan memiliki bentangan wilayah yang terluas di antara kecamatan yang lain dan berada dalam posisi di sebelah selatan ibu kota kabupaten Bandung dengan luas wilayah sebesar 27.295,71 ha dengan topografi berupa daratan, lereng atau punggung bukit. Kabupaten Bandung yang memiliki 31 Kecamatan terletak pada $107^{\circ} 22-108^{\circ} 50$ Bujur Timur dan $6^{\circ} 41-7^{\circ}$ 19 Lintang Selatan. Berdasarkan topografinya sebagian besar wilayah di kabupaten Bandung merupakan pegunungan atau daerah perbukitan dengan ketinggian di atas permukaan laut bervariasi dari $500 \mathrm{~m}$ sampai $1800 \mathrm{~m}$.

Kecamatan Pangalengan berada pada posisi sebelah timur berbatasan dengan kabupaten Garut dan sebelah barat berbatasan dengan kabupaten Cianjur. 
Kecamatan Pangalengan terletak sekitar $41 \mathrm{Km}$ ke arah selatan dari ibu kota propinsi Jawa Barat dan 23 $\mathrm{Km}$ jarak dari pusat pemerintahan kabupaten Bandung. Kecamatan Pangalengan bentangan alam atau bentuk wilayah dari datar sampai berombak sebesar $29 \%$ dan berombak sampai berbukit sebesar 33\% serta berbukit sampai bergunung sebesar 38\%. Kecamatan pangalengan berada pada pada ketinggian 1500 meter di atas permukaan laut dan memiliki suhu udara berkisar antara $13^{\circ} \mathrm{C}-25^{\circ} \mathrm{C}$ (Monografi Kecamatan Pangalengan 2015).

Kecamatan Pangalengan memiliki 13 Desa dan 43 Dusun yang tersebar dengan jumlah Kepala Keluarga sebanyak 32.725 orang pada tahun 2015 . yang berkomposisi jenis kelamin laki-laki lebih banyak dari perempuan serta untuk kepercayaan atau agama mayoritas beragama islam serta sisanya agama lain seperti Kristen, Hindu dan Budha. Sebagian wilayah Pangalengan terdapat prasarana pengairan seperti Waduk atau Situ dan Dam yang dipergunakan atau dimanfaatkan sebagai energi Listrik dari pihak PLN (Monografi Kecamatan Pangalengan 2015).

Sebagai daerah pegunungan, wilayah di Kecamatan Pangalengan mayoritas bermata pencaharian adalah petani, pedagang, buruh perkebunan, industri dan lain lain. Perbedaan ketinggian tempat tersebut akan menyebabkan keragaman vegetasi yang tumbuh di sana. Sektor pertanian dengan produk utama seperti kentang yang menjadi kebanggaan daerah ini, dan juga hasil palawija seperti wortel, kubis, kol dan lainlain. Sektor lain seperti perkebunan tetap menjadiikan prioritas utama bagi daerah ini walaupun ada yang milik swasta maupun milik negara. Sementara itu sub-sektor peternakan terutama peternakan sapi perah menjadikan Pangalengan terkenal akan sentra peternakan dan juga koperasinya yaitu KPBS.

\section{Perkembangan Peternakan Sapi Perah di Pangalengan}

Perkembangan peternakan sapi perah di Pangalengan kabupaten Bandung Propinsi Jawa Barat mendapat perhatian maksimal dan dipandang positif dari sisi peningkatan penghidupan peternak dan tambahan pendapatan daerah serta menjadikan wilayah ini menjadi pusat pengembangan sapi perah di Jawa Barat. Hal tersebut tidak terlepas dari keberadaan kelembagaan lokal di sektor peternakan sapi perah yang menjadikan keberlanjutan kehidupan para peternak sapi perah. Kondisi geografis dan ekologis Pangalengan sangat potensial bagi pembudidaya peternakan sapi perah telah memprekondisikan wilayah ini memiliki sejarah yang panjang dalam pengusahaan ternak sapi perah. Pengusahaan ternak sapi perah telah mewarnai baik sejarah, ekonomi, sosial budaya maupun politik di daerah pegunungan Pangalengan.
Menelusuri pengembangan peternakan sapi perah di Pangalengan Kabupaten Bandung tentu mengalami proses yang panjang dan berliku hingga akhirnya dapat diklasifikasi dalam beberapa periode. Periodisasi tersebut didasarkan atas berbagai hal diantaranya adalah kondisi dilapangan, berbagai kebijakan dan perkembangan KPBS. Periodisasi tersebut antara lain 1) Periode Penjajahan (sebelum tahun 1945); 2) periode Perintis (tahun 1945 sampai dengan tahun 1975); dan 3) periode Kontemporer (tahun 1975 sampai dengan sekarang).

Gambaran singkat dari periodisasi tersebut dari masa penjajahan hingga sekarang terlihat darimasuknya ternak sapi perah sebelum abad ke 19, sapi perah dari bangsa Fries Holland (FH) sudah berada di Indonesia khususnya pulau Jawa melalui proses impor dari negara Belanda. Perkembangan peternakan sapi perah semakin maju terbukti dari adanya perusahaan peternakan sapi perah di daerah Pangalengan antara lain : de Friesche Trep, Almanak, Van der Est dan Bigman. Perusahaan ini di bangun untuk kepentingan kolonial Belanda yang ada di sekitar Pangalengan dan di Bandung. Perusahaan peternakan sapi perah dikelola oleh pihak kolonial Belanda dan sebagai buruh ternaknya adalah masyarakat Pangalengan dan hasil produksi susu didistribusikan ke Bandoengsche Melk Center (BMC).

Selanjutnya dalam konteks perpolitikan luar negeri, bangsa Jepang akhirnya menjadi penjajah di Indonesia menggantikan Kolonial Belanda. Berbagai sektor dikelola oleh pihak Jepang tidak terlepas perusahaan peternakan sapi perah yang berada di Pangalengan. Tidak lama Jepang menguasai Indonesia kurang lebih tiga tahun setengah tetapi kondisi kehidupan bangsa Indonesia porak-poranda. Dieksploitasinya berbagai sumberdaya. Di sektor peternakan, populasi ternak sapi perah menurun karena sebagian ternak sapi perah yang harusnya diorientasikan sebagai penghasil susu tetapi malah sebaliknya. Konsumsi daginglah menjadi prioritas utama untuk kebutuhan tentara Jepang. Hal tersebut berdampak pada menurunnya jumlah populasi ternak sapi perah. Kekalahan Jepang dalam perang dunia ke II mengantarkan jepang untuk keluar dari wilayah negara Indonesia. Disektor peternakan khususnya sapi perah di Pangalengan yang sebelumnya dikelola oleh pihak Jepang akhirnya di sebar ternak tersebut ke para pegawai ataupun masyarakat sekitar Pangalengan.

Awal kemerdekaan sampai dengan sekarang, cikal bakal peternakan rakyat sudah ada di Pangalengan. Terlebih pada tahun 1949 dibentuknya GAPPSIP (Gabungan PetaniPeternak Sapi IndonesiaPangalengan). Kelembagaan ini hampir menyerupai koperasi. Fungsi dan perannya sangat bermanfaat bagi masyarakat Pangalengan. Namun kondisi kehidupan perpolitikan di negara Indonesia yang masih labil akhirnya bubar dan sebagai penggantinya, pada tahun 1969 dibentuk 
sebuah koperasi primer peternakan sapi perah yaitu KPBSyang berbadan hukum. Institusi ini memberikan pengaruh yang besar terhadap kehidupan masyarakat Panglengan. Dinamika perkembangan terjadi di lembaga ini, mulai dari kurangnya bibit, keberadaan cooling unit ataupun Milk Treatment, penyediaan ternak melalui kredit, masalah hubungan sosial, dan kebijakan pemerintah yang tidak selalu memihak kepada peternak sapi perah. Dalam konteks ini dapat dikemukakan, bahwa pengembangan pengusahaan ternak sapi perah sejak jaman kolonial Belanda sampai dengan Indonesia kontemporer menunjukkan dinamika dan perubahaperubahan penting terutama dalam tingkat struktur atau 'pemain' dalam peternakan sapi perah sebagaimana tampak pada matrik Tabel 1.

\section{Moda Produksi}

Pemahaman moda produksi mengacu pada "mode of production" yang merupakan kombinasi dan dua elemen penting yang saling terkait, yaitu "force of production" (kekuatan produksi) dan "relation of production" (hubungan produksi) yang membahas mengenai realitas sosial dalam membentuk sebuah sejarah yang spesifik dari organisasi sosial. Secara umum, moda produksi merepresentasikan "cara" yang ditempuh masyarakat dalam melakukan proses produksi (way of production) guna menyediakan produk untuk memenuhi kebutuhan materil (Shanin, 1990).

Moda produksi terartikulasikan pada kehidupan sehari-hari dalam kegiatan-kegiatan ekonomi (Rusell, 1989). Artikulasi merupakan bentuk strukturalisasi moda produksi pada budaya setempat berbentuk kegiatan-kegiatan ekonomi seperti pertanian, kerajinan, perkebunan, peternakan, perdagangan, pariwisata, dan jenis-jenis kegiatan ekonomi lainnya. Masing-masing kegiatan ekonomi dapat mencerminkan moda produksi apa yang digunakan, dengan melihat ciri-ciri kekuatan produksi dan hubungan/ relasi sosial produksinya. Perkembangan usaha peternakan sapi perah di Pangelangan tidak terlepas dari perjalanan waktu yang cukup panjang. Dengan dasar tersebut dapat di analisis moda produksi berdasarkan periodisasi kejadian. Periodisasi kejadian dalam hal ini adalah tinjauan secara historis dalam perkembangan moda produksi usaha peternakan sapi perah. Hal tersebut bertujuan untuk memetakan periodisasi kejadian dari masa ke masa dalam perkembangan usaha peternakan sapi perah di Pangalengan Jawa Barat. Pembagian periode tersebut berdasarkan faktor dominan yang mempengaruhi moda produksi usaha peternakan sehingga terjadi perubahanperubahan.

\section{Periode Penjajahan (Sebelum tahun 1945)}

Periode ini merupakan awal dari pembentukan usaha peternakan sapi perah, diawali dari masa kolonial Belanda dilanjutkan dengan penjajahan oleh Negara Jepang. Periode penjajahan ini merupakan masa pembentukan formasi sosial kapitalis awal, hal tersebut di tandai dengan masuknya moda produksi kapitalis kolonial melalui perkebunan sebagai artikulasinya. Sedangkan moda produksi selanjutnya dilanjutkan pada usaha peternakan sapi perah yang sama menganut atau

Tabel 1. Struktur 'pemain' Pada Peternakan Sapi Perah

\begin{tabular}{|c|c|c|c|}
\hline Periode & Pemain & Pola Hubungan & Posisi Peternak \\
\hline $\begin{array}{l}\text { Kolonial } \\
\text { Belanda }\end{array}$ & $\begin{array}{l}\text { - Pemerintah kolonial } \\
\text { - Dinas Kehewanan / Jawatan Kehewanan } \\
\text { - Perusahaan Peternakan Sapi Perah } \\
\text { - Buruh Ternak (pribumi) }\end{array}$ & $\begin{array}{l}\text { Industrial } \\
\text { Monopolistik }\end{array}$ & $\begin{array}{l}\text { Dominasi kekuatan } \\
\text { kapitalis }\end{array}$ \\
\hline $\begin{array}{l}\text { Imperialis } \\
\text { Jepang }\end{array}$ & $\begin{array}{l}\text { - Pemerintah Jepang } \\
\text { - Dinas Kehewanan } \\
\text { - Perusahaan Peternakan Sapi Perah } \\
\text { - } \text { Buruh ternak (pribumi) }\end{array}$ & $\begin{array}{l}\text { Industrial } \\
\text { Monopolistik }\end{array}$ & $\begin{array}{l}\text { Dominasi kekuatan } \\
\text { kapitalis }\end{array}$ \\
\hline $\begin{array}{l}\text { Awal } \\
\text { Kemerdekaan }\end{array}$ & $\begin{array}{l}\text { - Peternak skala kecil } \\
\text { - Kelembagaan lokal } \\
\text { - } \text { Kolektor } \\
\text { - Pedagang } \\
\text { - } \text { Buruh Ternak }\end{array}$ & Saling ketergantungan & $\begin{array}{l}\text { Peternak dalam } \\
\text { kontrol kolektor dan } \\
\text { kelembagaan lokal } \\
\text { (Gappsip) }\end{array}$ \\
\hline $\begin{array}{l}\text { Indonesia } \\
\text { Kontemporer }\end{array}$ & $\begin{array}{l}\text { - Pemerintah (Perdagangan, dan Peternakan ) } \\
\text { - Koperasi } \\
\text { - Perusahaan Peternakan Sapi Perah } \\
\text { - Pedagang } \\
\text { - Pengusaha } \\
\text { - Peternak (Subsisten, menengah dan Besar) } \\
\text { - } \text { Buruh ternak }\end{array}$ & Saling ketergantungan & $\begin{array}{l}\text { Peternak dalam } \\
\text { kontrol dan } \\
\text { pengelolaan koperasi }\end{array}$ \\
\hline
\end{tabular}


teradaptasi pada kapitalis kolonial. Usaha peternakan sapi perah yang dibangun pada masa kolonial Belanda terbentuk kurang lebih pada tahun 1860 . Orientasi awal pihak kolonial dalam mengembangkan peternakan sapi perah tidak lain adalah untuk pemenuhan kebutuhan mereka dalam mengkomsumsi susu dan komersialisasi.

Penyebaran ternak sapi di daerah Pangalengan pada waktu ini tidak sebanyak yang sekarang. Empat perusahaan yang berkembang diantaranya de Friesche Trep, Almanak, Van der Est dan Bigman (Dasuki, 1983). Keempat perusahaan tersebut terletak di Pangalengan. Pangalengan dulu dan sekarang berbeda, yang membedakannya adalah dulu hanya satu wilayah yaitu pangalengan tapi sekarang terjadi pemekaran sehingga Kecamatan Pangalengan terbagi menjadi 13 Desa. Salah satu informan menyebutkan bahwa nama Pangalengan yang sekarang berasal dari kata pengalengan, yang menurut informan menyebutkan bahwa kantor Kecamatan yang sekarang berdiri berawal dari tempat pengalengan kopi. Komoditas utama dari Pangalengan pada masa ini adalah perkebunan kopi, teh dan kina.

Moda produksi kapitalis diartikulasikan sebagai perkebunan kopi, teh dan kina, produksi berorientasi ekspor dengan perusahaan sebagai unit produksi. Teknologi budidaya dan alat yang digunakan perkebunan lebih modern. Paling tidak sudah diperkenalkan mesin angkut dan pengolahan hasil perkebunan. Tenaga kerja mengandalkan buruh upahan sehingga hubungan sosial produksi lebih cenderung kearah hubungan hierarkis.

Awal pembentukan moda produksi yang diartikulasikan sebagai perkebunan terus berjalan hingga saat ini. Selanjutnya, moda produksi yang diartikulasikan sebagai usaha peternakan sapi perah yang berkembang pada masa ini hingga sekarang masih berjalan. Artikulasi peternakan hampir sama dengan artikulasi perkebunan dalam cara atau moda produksi, yang membedakan adalah pergunaan alat teknologi. Kekuatan produksi peternakan mengandalkan kemampuan modal untuk menggerakan produksi. Ternak sapi perah sebagai kekuatan produksi utama dilanjutkan dengan lahan dalam pengembalaan atau penyediaan hijauan, serta kandang yang disiapkan untuk ternak sapi. Begitupun hubungan produksi usaha peternakan bersifat hierarkis. Perkembangan cara produksi kapitalis Belanda di Pangalengan tidak dapat dipisahkan dari skema kapitalisme kolonial secara nasional dan dunia. Mengenai aspek moda produksi tersebut diuraikan dalam Tabel 2 sebagai berikut:

\section{Periode Perintis (tahun1945 sampai 1979)}

Pada periode ini seluruh aktivitas peternakan sapi perah sudah tidak seperti pada jaman penjajahan. Ternak sapi perah yang dipelihara oleh warga sekitar sebagai dampak dari menyerahnya jepang terhadap sekutu. Ternak sapi perah yang ada di perusahaan peninggalan Belanda dilimpahkan kepada Jepang selanjutnya dengan kekalahan jepang sisa-sisa ternak banyak dipelihara oleh warga sekitar selanjutnya dikatakan sebagai bakal dalam pengembangan peternakan sapi perah di Pangalengan.

Pengembangan peternakan sapi perah tidak semulus apa yang dicita-citakan, tantangan terbesar adalah bagaimana keberlanjutan peternakan sapi perah tetap berjalan sedangkan ketidaktersedianya konsentrat atau pakan pendukung selain hijauan yang susah untuk diperoleh dan juga hasil pemerahan yang berupa susu yang tidak mungkin untuk dikomsumsi terus menerus dengan kata lain butuh pasar alias konsumen dalam penerimaan susu segar. Pada periode ini mengalami ketidakpastian dalam usaha peternakan sapi perah dan akhirnya untuk mendukung hal tersebut para tokoh masyarakat Pangalengan membentuk suatu kelembagaan yang dinamakan GAPPSIP.

Dibentuknya Gappsip memberikan ruang untuk dapat mengembangkan usaha peternakan lebih maju. Tapi hal tersebut tidak dapat dilaksanakan dengan maksimal. Masalah yang dihadapi adalah masalah internal dan eksternal yaitu ketidaksalingpercayaan diantara anggota dengan pengurus dan situasi serta kondisi perpolitikan Negara Indonesia yang masih labil. Hal tersebut mempengaruhi kehidupan para petani peternak sapi perah yang ada di Pengalengan. Berbicara cara atau moda produksi sebagai artikulasi peternakan sapi perah maka tidak terlepas dari kekuatan produksi dan hubungan produksi. Kekuatan produksi yang tercermin dari penguasaan jumlah ternak dan luasnya lahan yang diperuntukan untuk kandang dan pakan hijauan. Perbedaan yang dirasakan pada periode ini adalah tidak adanya penekanan atau eksploitasi dari pihak lain dalam hal ini penjajah. Keluarga inti

Tabel 2. Moda produksi Capitalist Kolonial Belanda dan subsistence

\begin{tabular}{llll}
\hline & \multicolumn{1}{c}{ Aspek Moda Produksi } & \multicolumn{1}{c}{ Capitalist Kolonial } & \multicolumn{1}{c}{ Subsistence } \\
\hline A & Kekuatan Produksi & & \\
1 & Alat Produksi & Ternak Sapi perah \& Lahan & Ternak Sapi perah \& Lahan \\
2 & Organisasi (unit) Produksi & $\begin{array}{l}\text { Perusahaan } \\
\text { Buruh Upahan }\end{array}$ & $\begin{array}{l}\text { Keluarga Inti } \\
\text { Keluarga Inti }\end{array}$ \\
3 & Tenaga Kerja Utama & & \\
B & Hubungan Produksi & Keluarga Inti \\
1 & Batas Sosial Hubungan Produksi & Perusahaan & Egaliter (antar keluarga inti) \\
2 & Struktur Hubungan Produksi & Hierarkis (majikan dan buruh) & Non-Eksploitatif \\
3 & Sifat Hubungan Produksi & Eksploitatif &
\end{tabular}


sebagai motor atau pekerja dalam usaha peternakan sapi perah. Sedangkan, hubungan produksi tercermin dari kekeluragaan dalam hal ini peran keluarga dan tidak ada eksploitasi. Mengenai aspek moda produksi tersebut diuraikan dalam Tabel 3 sebagai berikut :

\section{Periode Kontemporer (tahun 1975 sampai sekarang)}

Periode ini merupakan periode gemilang dengan artian bahwa jumlah atau kuantitas dan kualitas ternak di Pangalenganmeningkatcukupbanyak. Denganbegitupara peternak pun ikut bertambah banyak sehingga pekerjaan pun menjadi lebih terbuka. Hal yang menjadikan kondisi ini menjadi lebih baik dari sebelumnya adalah adanya itikad untuk memperbaiki institusi yang sudah pernah ada dan berkembang di Pangalengan yaitu Gappsip. Institusi ini tidak berjalan lagi setelah ketidakmampuan untuk mengelola organisasi dan kondisi perpolitikan yang belum stabil. Tahun 1969 merupakan awal dari pembentukan pembangunan Negara Indonesia melalui Pelita dan Repelita yang tertuang dalam GBHN. Dengan waktu yang bersamaan pula daerah Pangalengan dengan para penggagas dan para tokoh masyarakat kembali membangun usaha peternakan sapi perah menjadi lebih baik yaitu dengan dibentuknya KPBS.
Dinamika perkembangan dalam KPBS pun terjadi, seperti pembangunan Milk Treatment dan pembangunan pabrik konsentrat serta upaya pemasaran hasil olahan susu. KPBS yang diperuntukan hanya untuk peternak bukan untuk umum, sehingga KPBS sebagai koperasi primer yang ada di Jawa Barat selain yang ada di lembang (KPSBU). Pada periode ini terdapat banyak perubahan dalam pengembangan usaha peternakan sapi perah diantaranya pelaksanaan kawin ternak melalui teknologi inseminasi buatan yang menjadikan awal dalam modernisasi di bidang peternakan, selanjutnya penguatan institusi atau kelembagaan koperasi yang dioptimalkan baik sarana maupun sumber daya manusianya.

Dinamika perkembangan peternakan sapi perah tidak selesai dengan dibetuknya sebuah institusi yang menaungi para peternak sapi perah. Melainkan bagaimana keberlanjutan usaha para peternak sapi perah di Pangalengan siap menghadapi penetrasi modernisasi peternakan. Moda produksi yang berkembang di Pangalengan pada periode kontemporer ini dibagi dalam ` moda produksi, antara lain: moda produksi petty commodity dan moda produksi capitalist yang diartikulasikan peternakan sapi perah. Mengenai aspek moda produksi tersebut diuraikan dalam Tabel 4 sebagai berikut:

Tabel 3. Moda produksi Subsistence dan Moda Produksi Semi-Petty Commodity

\begin{tabular}{|c|c|c|}
\hline Aspek Moda Produksi & Subsistence & Semi-Petty Commodity \\
\hline \multicolumn{3}{|l|}{ A. Kekuatan Produksi } \\
\hline 1. Alat Produksi & Ternak Sapi dan Lahan & Ternak Sapi dan Lahan \\
\hline 2. Organisasi (unit) Produksi & Keluarga Inti & Keluarga Inti \\
\hline 3. Tenaga Kerja Utama & Keluarga Inti & Keluarga Inti + (pegawai) Buruh ternak \\
\hline \multicolumn{3}{|l|}{ B. Hubungan Produksi } \\
\hline 1. Batas Sosial Hubungan Produksi & Keluarga Inti & Keluarga Inti \\
\hline $\begin{array}{l}\text { 2. Struktur Hubungan Produksi } \\
\text { 3. Sifat Hubungan Produksi }\end{array}$ & $\begin{array}{l}\text { Egaliter (antar keluarga inti) } \\
\text { Non-Eksploitatif }\end{array}$ & $\begin{array}{l}\text { Potensi Hirearkis, lebih banyak Egaliter } \\
\text { (antar keluarga inti) Non-Eksploitatif }\end{array}$ \\
\hline
\end{tabular}

Sumber informasi: diolah dari berbagai sumber

Tabel 4. Moda Produksi Moda Produksi Petty Commodity dan Moda Produksi Capitalist

\begin{tabular}{|c|c|c|}
\hline \multirow{2}{*}{$\begin{array}{c}\text { Aspek Kekuatan } \\
\text { Produksi }\end{array}$} & \multicolumn{2}{|c|}{ Moda Produksi } \\
\hline & Petty Commodity & Capitalist \\
\hline $\begin{array}{l}\text { Alat Produksi/ } \\
\text { modal }\end{array}$ & $\begin{array}{l}\text { - } \text { Lahan (kandang, kebun rumput) } \\
\text { - } \text { Jumlah ternak sapi laktasi (induk) lebih dari } \\
3 \text { ekor } \\
\text { - } \text { Kandang Konvensional } \\
\text { - } \text { Milkcan ukuran } 10 \text { dan } 15 \text { liter }\end{array}$ & $\begin{array}{ll}\text { - } & \text { Lahan (kandang, kebun rumput) } \geq 1 \text { ha } \\
\text { - } & \text { Jumlah ternak sapi laktasi (induk) } \geq 1000 \text { ekor } \\
\text { - } & \text { Kandang Permanen } \\
\text { - } & \text { Gudang pakan } \\
\text { - } & \text { Mesin perah permanen langsung ke } \\
& \text { penyimpanan (cooling } \text { unit) }\end{array}$ \\
\hline Produksi susu & $10-15$ liter / hari/ ekor & $30-35$ liter / hari/ ekor \\
\hline Penyaluran Susu & TPK , Milk Treatment & IPS \\
\hline Unit Produksi & Keluarga Inti & Karyawan, buruh ternak \\
\hline $\begin{array}{l}\text { Tenaga Kerja } \\
\text { Utama }\end{array}$ & Anggota keluarga inti + pegawai (buruh ternak) & Karyawan, buruh ternak \\
\hline $\begin{array}{c}\text { Aspek Hubungan } \\
\text { Produksi }\end{array}$ & & \\
\hline $\begin{array}{l}\text { Pola Hubungan } \\
\text { Produksi }\end{array}$ & $\begin{array}{l}\text { Batas Sosial : Jumlah tenaga kerja tercukupi } \\
\text { oleh famili + pegawai (buruh ternak) } \\
\text { Struktur: egaliter (antar anggota keluarga inti), } \\
\text { potensi hierarkis pada skala kepemilikan besar } \\
\underline{\text { Sifat Produksi : Non-eksploitatif }}\end{array}$ & 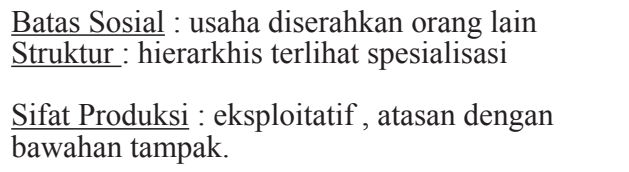 \\
\hline $\begin{array}{l}\text { Pola Hubungan } \\
\text { Pemasaran }\end{array}$ & Langsung berhubungan dengn koperasi & Tidak ada perantara langsung dengan pabrik/ IPS \\
\hline
\end{tabular}


Moda produksi pada periode ini dalam artikulasi usaha peternakan sapi perah tidak jauh berbeda dari periode sebelumnya. yaitu di lihat dari kekuatan produksi masih tertuju pada jumlah penguasaan ternak dan luasnya lahan yang dimiliki ditambah dengan keterampilan beternak sudah lebih baik. Walaupun kondisi ini sudah tidak seperti dahulu. Lahan yang ada sudah mulai atau mengalami kekurangan luasnya dikarenakan dipergunakan untuk keperluan rumah tangga, tempat pendidikan, kantor dan lain-lain. Lahan merupakan modal utama dalam berusahatani dan sangat menentukan kemandirian petani dalam menentukan keputusan sendiri yang terbaik bagi pengembangan dan keberlanjutan usaha (Malta, 2016). Kecenderungan yang muncul dalam hal kekuaran produksi adalah terlihatnya pembagian kerja dengan jelas sampai sudah memunculkan adanya buruh ternak, walaupun buruh ternak tersebut masih dalam satu keluarga ataupun tetangga dekat. Hubungan produksi yang terjadi ada kecenderungan kepada hirearkis walaupun tidak semua peternak tapi ada sebagian peternak yang demikian dikarenakan jumlah ternak yang dimiliki sudah lebih dari 10 ekor induk yang laktasi sehingga membutuhkan buruh ternak.

Kekuatan produksi yaitu ternak sapi perah dan lahan sebagai pakan hijauan dan pembatasan kandang serta keterampilan peternak. Selanjutnya yang bekerja masih yang mendominasi adalah keluarga inti. Walaupun kecenderungan akan buruh ternak masih ada. Hubungan produksi tidak tereksploitatif walaupun terdapat buruh ternak. Karena buruh yang bekerja adalah saudara jauh atau tetangga sehingga menjaga perasaan atau saling menghormati tetap berlangsung walaupun posisi sebagai buruh ternak. Struktur hubungan produksi yang tampak cenderung hierarkis tapi lebih banyak egaliter walaupun buruh ternak sudah dilibatkan dalam usaha peternakan sapi perah. Sementara itu moda produksi kapitalis yang berkembang atas penetrasi kapital oleh Industri Pengolahan Susu memberikan gambaran tentang pola hubungan produksi melalui batas sosial yaitu usaha yang dijalankan menggunakan atau diserahkan kepada orang lain, struktur hubungan produksi tergambarkan hierarkis dan sifat produksi jelas mengarah kepada eksploitasi. Berdasarkan moda produksi yang terbentuk pada periode kontemporer maka formasi sosial yang terjadi adalah moda produksi petty commodity, lihat Russel, 1989.

Hal tersebut dikarenakan dalam usaha produksi orientasi kepada komoditi susu menjadi fokus utama dan masih ditindak lanjuti hingga sekarang walaupun berbagai kebijakan pemerintah yang tidak pro terhadap peternakan sapi perah rakyat.Melihat periodisasi dalam pembentukan moda produksi pada usaha peternakan sapi perah mencerminkan adanya dinamika atau transformasi dalam pengembangan usaha peternakan sapi perah. Formasi sosial yang terbentuk di tiaptiap periode mencerminkan bahwa banyaknya moda produksi yang berkembang tetapi hanya satu yang dominan pada masyarakat atau komunitas peternak sapi perah. Selanjutnya, bahwa dalam perkembangan usaha peternakan sapi perah di Pangalengan dari awal pembentukan hingga sekarang diperoleh beberapa perubahan dalam manajemen beternak sapi perah diantaranya adalah munculnya pekerjaan baru dan pembagian kerja dalam beternak sapi perah.

\section{SIMPULAN}

Berdasarkan hasil dan pembahasan dapat diambil beberapa kesimpulan antara lain : pengembangan peternakan sapi perah di Pangalengan dapat diklasifikasikan berdasarkan periodisasi waktu yaitu periode penjajahan (sebelum tahun 1945), periode perintis (tahun 1945 sampai 1975) dan periode kontemporer (tahun 1975 sampai sekarang). Disetiap periode diperoleh gambaran mengenai moda produksi yang terbentuk. pada periode sebelum kemerdekaan atau sebelum tahun 1945 hanya terbentuk moda produksi kapitalis, pada masa perintis yaitu pada tahun 1945 sampai dengan tahun 1975 terlihat muculnya dua moda produksi yaitu moda produksi subsistence dan moda produksi semi-petty commodity, dan yang terakhir adalah pada periode kontemporer yaitu dimulai tahun 1975 sampai sekarang terbentuk dua moda produksi usaha peternakan yang berkembang yaitu moda produksi petty commodity serta moda produksi Capitalist. Dari kedua moda produksi tersebut yang mendominasi usaha peternakan sapi perah di Pangalengan adalah moda produksi petty commodity.

\section{DAFTAR PUSTAKA}

Creswell, John W. 1994. Research Design :Qualitative and Quantitative Approaches. California: Sage Publication. Inc.

Dasuki M. A. 1983. Perspektif Perkembangan Peternakan Sapi Perah Sebagai landasan Kesepadanan Mengisi Kebutuhan Susu di Jawa Barat. (Disertasi), Universitas Padjadjaran. Bandung

Homzah, Siti. 1986. Peranan Wanita dalam Usaha Ternak Sapi Perah Rakyat (Studi Kasus di Desa Pangalengan Kabupaten Bandung). (Tesis). Sekolah Pascasarjana Institut Pertanian Bogor. Bogor

Malta, 2016. Faktor-faktor yang Berhubungan dengan Kemandirian Petani dalam Pengambilan Keputusan untuk Keberlanjutan Usahatani. Sosiohumaniora. 18 (2), 108-114. 
Shanin, Teodor. 1990. Defining Peasant. Essays Concerning Rural Societies, Expolary Economies, and Learning from them in the Contemporary Wolrd. Basil Blackwell. Cambridge.

Russel, W. James, 1989. Modes of Production in World History, London and New York, Routlge.
Subandriyo dan Ardiarto, 2009. Sejarah Perkembangan Peternakan Sapi Perahdalam Profil Usaha Peternakan Sapi Perah di Indonesia Oleh Santosa, dkk. LIPI Press. Bogor.

Yin. 2002. Metode Studi Kasus. Jakarta: Rajagrafindo Persada. 